\title{
Exploring the relationship between entrepreneurial behavior and teachers' job satisfaction
}

do Carmo Amorim Neto, Roque; Rodrigues, Vinicius Picanco; Panzer, Shannon

Published in:

Teaching and Teacher Education: An International Journal of Research and Studies

Link to article, DOI:

10.1016/j.tate.2017.01.001

Publication date:

2017

Document Version

Peer reviewed version

Link back to DTU Orbit

Citation (APA):

do Carmo Amorim Neto, R., Rodrigues, V. P., \& Panzer, S. (2017). Exploring the relationship between entrepreneurial behavior and teachers' job satisfaction. Teaching and Teacher Education: An International Journal of Research and Studies, 63, 254-262. https://doi.org/10.1016/j.tate.2017.01.001

\section{General rights}

Copyright and moral rights for the publications made accessible in the public portal are retained by the authors and/or other copyright owners and it is a condition of accessing publications that users recognise and abide by the legal requirements associated with these rights.

- Users may download and print one copy of any publication from the public portal for the purpose of private study or research.

- You may not further distribute the material or use it for any profit-making activity or commercial gain

- You may freely distribute the URL identifying the publication in the public portal 


\title{
Exploring the Relationship Between Entrepreneurial Behavior and Teachers' Job
}

\section{Satisfaction}

\author{
ROQUE DO CARMO AMORIM NETO ${ }^{a^{*}}$ \\ Given Name: Roque do Carmo \\ Family Name: Amorim Neto \\ ${ }^{a}$ College of Urban Education, Davenport University. 6191 Kraft Ave. Grand Rapids, MI 49512, \\ USA. Phone: 616.544.5063. E-mail: roque.neto@davenport.edu
}

\author{
VINICIUS PICANCO RODRIGUES ${ }^{\mathrm{b}}$ \\ Given Name: Vinicius \\ Family Name: Picanco Rodrigues \\ ${ }^{\mathrm{b}}$ Section of Engineering Design and Product Development, Department of Mechanical \\ Engineering, Technical University of Denmark. Produktionstorvet, Building 426, 2800 - \\ Kgs.Lyngby, Denmark. Phone: +45 452541 53. E-mail: vipiro@dtu.dk
}

\section{SHANNON PANZER ${ }^{c}$}

Given Name: Shannon

Family Name: Panzer

'College of Urban Education, Davenport University. 6191 Kraft Ave. Grand Rapids, MI 49512, USA. Phone: 813.210.5799. E-mail: spanzer@email.davenport.edu

*Correspondence concerning this article should be addressed to Roque do Carmo Amorim Neto College of Urban Education, Davenport University. 6191 Kraft Ave. Grand Rapids, MI 49512, USA. Phone: 616.544.5063. E-mail: roque.neto@davenport.edu

This research did not receive any specific grant from funding agencies in the public, commercial, or not-for-profit sectors. 


\title{
Exploring the Relationship Between Entrepreneurial Behavior and Teachers' Job Satisfaction
}

\begin{abstract}
:
This exploratory study has two goals: exploring the relationship between entrepreneurial behavior and job satisfaction among teachers, and identifying the demographic characteristics associated with both variables. Using a snowball technique, a sample of $385 \mathrm{~K}-12$ Brazilian teachers from public and private schools responded to the survey. Statistical analysis revealed a moderate correlation between entrepreneurial behavior and job satisfaction. Results also show that gender and educational level are associated with entrepreneurial behavior. The discussion includes theoretical and practical implications.
\end{abstract}

Keywords: competency-based, entrepreneurship, demographic characteristics, teachers' job satisfaction 


\section{Introduction}

The value of entrepreneurs and entrepreneurial thinking is evident in most countries, where innovative, enterprising individuals are highly respected and often perceived as a key engine for regional economic growth and development (Fritsch \& Wyrwich, 2016). Consider those such as Henry Ford and Steve Jobs, who have defined the entrepreneur as someone starting a new business or taking advantage of cutting-edge technology to make financial gains (Maranto, 2015). The term "entrepreneur" has been in use since being cited in the 1700 s to describe "a rational decision maker who assumes the risk and provides management for the firm" (Carland, Hoy, \& Carland, 1988, p. 33). Despite the term's longevity, alternate definitions abound in current literature. Entrepreneurs, according to Tülüce and Yurtkur (2015), take advantage of opportunities and use innovation and technology to achieve advancement in the marketplace. For Borasi and Finnigan (2010), entrepreneurship converts knowledge into endeavors that provide value, whether financial, scholastic, or communal in nature. Petersen (2014) defines the entrepreneur as an individual with the vision to start a new organization or business in response to opportunities that make a difference in people's lives. These definitions may hold true for business entrepreneurship; however, the educational field needs a more attentive look.

Entrepreneurship in education has received increased attention in recent years, from both scholars and practitioners (Chand, 2014; Omer Attali \& Yemini, 2016). Van Dam, Schipper, and Runhaar (2010) define entrepreneurship as a behavior "that involves recognizing opportunities and marshaling the resources to take advantage of, and acting upon these opportunities" (p. 966). Within the educational setting, entrepreneurial behavior has to do with the ability to effectively 
explore innovative ideas, stimulate students to think critically and creatively, continuously search for new developments in areas connected to the educational field, develop compelling technology-based projects inside and outside the classroom, and find the necessary resources to implement students' learning (Van Dam et al., 2010). Teachers are not expected simply to be sources of knowledge, but rather to develop entrepreneurial actions towards building a better educational system, thereby influencing their roles and general conduct. They are expected to identify and seek opportunities, take initiative and display proactive behavior to seize those opportunities, and take calculated risks in order to succeed (Onstenk, 2003; Tolentino, 1998; Van Dam et al., 2010).

Moreover, educators are also constantly perceived as role models for their students (Lunenberg, Korthagen, \& Swennen, 2007), from whom - as future employees - entrepreneurial behavior is increasingly requested, from both young startup companies as well as established organizations. In that sense, teachers can have a large influence over the course of their students' careers by displaying solid entrepreneurial-oriented skills and competencies in the classroom. This type of teacher's behavior might also spark the students' interest in initiating their projects and executing their own ideas since it provides interaction with people with same interests or “like themselves” (Burke \& McKeen, 1990; Burke, McKeen, \& McKenna, 1994; Oppedisano \& Laird, 2006).

Furthermore, entrepreneurship has been widely explored from both trait-based (Chell, 1985, 2000; Cools \& den Broeck, 2007; Zhang et al., 2009) and competency-based perspectives. The trait-based view heavily relies on the idea that entrepreneurs are born with certain characteristics rather than developing them with training and experience, whereas the 
competency-based view highlights competencies that can be cultivated through proper training (Van Dam et al., 2010). The competency-based view shows some advantages related to the possibility of recognizing and assessing its occurrence, with relevant implications for practitioners (Hayton \& Kelley, 2006; Van Dam et al., 2010). Therefore, we will adopt the competency-based perspective in this paper as a fundamental theoretical framework.

Since teachers are key elements to influencing student achievement within educational systems (Hoekstra, 2014) and teachers' satisfaction leads to better retention and effective instruction, satisfied teachers are directly associated with enhanced educational outcomes (Hoekstra, 2014; Song \& Mustafa, 2015). Furthermore, many studies have been devoted to understanding the relationship between entrepreneurship/self-employment and job satisfaction

(e.g. Bradley \& Roberts, 2004; Carree \& Verheul, 2012; Lange, 2012; Rietveld, Hessels, \& Van Der Zwan, 2015; Sankelo \& Åkerblad, 2009; Yetim \& Yetim, 2006). However there is little literature examining the link between entrepreneurship and job satisfaction in education, and even less when considering the K-12 public school system. Therefore, this research aims to explore the relationship between entrepreneurial behavior and job satisfaction among teachers, and identifying the demographic characteristics associated with both variables.

\section{Theoretical background}

\subsection{Entrepreneurship in Education}

While the idea of entrepreneurship has been around for many years, connecting it to education is a much more recent phenomenon (Borasi \& Finnigan, 2010). While the general definitions of entrepreneurship include bringing together ideas, capital and resources, or empowerment and creativity (Ali, Topping, \& Tariq, 2009; Borasi \& Finnigan, 2010; Foote, 
2012; Maranto, 2015), educational entrepreneurs are described as altruistic, ideological, and wanting to make a difference by impacting and improving the academic environment and responding to students' needs (Aurini \& Quirke, 2011; Maranto, 2015). Foote (2012) sees educational entrepreneurs as idea people who bring resources, empowerment, passion, and excitement into the classroom while creating solutions to educational problems. Maranto (2015) describes the educational entrepreneur as someone who sees public service as a quasi-religious calling, who is the antithesis of conventional organization, who sees problems that others do not, and who devises novel solutions to those problems. Sharra (2005) portrays educational entrepreneurship as a desire to solve social problems, pioneer change, and promote community service. Webber and Scott (2008) define it as a strategic focus incorporating planning, responsible and timely decision-making, and networking in order to create opportunities for learning. The general idea behind these varied definitions is that the educational entrepreneur is less concerned with material gains while managing scarce resources and employing creative teaching strategies for the betterment of their students.

More recently, terms such as "edu-preneur" (Foote, 2012) and "teacherpreneurship" (Davis, 2009) have begun to appear in literature, and the characteristics associated with this concept are being studied and quantified. Several studies have been published with compelling results. Aurini and Quirke (2011) performed 80 interviews with schooling organizations in Canada to determine how educational entrepreneurs interpret market competition and respond to it. Market theory supposes that competition makes organizations respond with services differentiated from, and better than, their competitors. However, this study found that educational entrepreneurs were largely unaware of their competition and more concerned with 
ideological commitments than with market forces. Ali et al. (2009) surveyed 516 prospective teachers in Pakistan, exploring their entrepreneurial inclinations and analyzing the factors of entrepreneurialism. The subjects were positively disposed toward entrepreneurship. Through factor analysis, this survey identified three predominant factors: entrepreneurial intent and acceptability, entrepreneurial effort, and entrepreneurial motivation. It also revealed a high demand for entrepreneurship courses in the training of prospective teachers. Borasi and Finnigan (2010) reported on six case studies of educators in the United States who have become successful change agents using entrepreneurial concepts. Using cross-analysis of these case studies, they identified ten behaviors and attitudes — such as creative thinking and networking skills - that contributed to the educators' success and that they suggest being included in teacher preparation or professional development courses (Borasi \& Finnigan, 2010). These studies are opening up new avenues, not only for prospective teachers, but also for frustrated educators seeking autonomy from dictated conventions such as teaching to the test and orchestrated curricula (Gunzenhauser, 2013).

Looking more closely at characteristics of the entrepreneur, Van Dam et al. (2010) questioned 251 teachers in the Netherlands and investigated six competencies expected to contribute to teachers' entrepreneurial behavior: entrepreneurial knowledge, career adaptability, occupational self-efficacy, creative thinking, networking skills, and teamwork skills. The results of this study showed that career adaptability and creative thinking were strongly linked to teacher's entrepreneurial behavior, while entrepreneurial knowledge, networking skills, and teamwork skills were less strong yet still significant. Interestingly, occupational self-efficacy did not have a significant outcome on teachers' entrepreneurial behavior. Based on these findings, 
Van Dam et al. (2010) argue that educational entrepreneurs can be developed, and vocational education programs should incorporate this development in their curricula to provide teachers with the foundation to cultivate entrepreneurial behavior, much as the previously described studies have also recommended.

2.2. Job Satisfaction: The Teacher's Perspective

Job satisfaction can be generally defined as "the positive or negative evaluative judgments that people make about their jobs" (Skaalvik \& Skaalvik, 2015, p. 181), an intrinsic attitude derived from the attainment of wants and needs from one's career experiences (Hoekstra, 2014), and how people feel about their jobs (Kitchel et al., 2012). Where teachers are concerned, job satisfaction also incorporates factors such as safe working conditions, salary and performance incentives, professional esteem and recognition, job security, a supportive administration, and autonomy (Foor \& Cano, 2011; Matsuoka, 2015; Skaalvik \& Skaalvik, 2015; Tran, 2015). On the other hand, lower levels of job satisfaction among educators result from increased time pressures, behavior and disciplinary problems, and stress (Matsuoka, 2015; Skaalvik \& Skaalvik, 2015; Tran, 2015). Hoekstra (2014) states that the teacher is the most important factor affecting student achievement in the classroom. Therefore, a happy teacher translates to increased student persistence and better educational outcomes.

Recognizing that teacher job satisfaction leads to retention, commitment, productivity, and effective instruction, this is a crucial issue when discussing teacher shortages and instructional quality (Hoekstra, 2014; Kitchel et al., 2012; Song \& Mustafa, 2015). Administrators should consider job satisfaction as a vital ingredient for success among faculty. It not only leads to job stability and increased motivation, but also enhanced cooperation with 
supervisors; better interpersonal relationships with colleagues, parents and students; and improved quality of instruction (Foor \& Cano, 2011; Hoekstra, 2014; Tran, 2015). Considering the high percentage of teachers contemplating retirement or leaving education due to job dissatisfaction, coupled with the high cost of recruiting new teachers, a need exists to examine the factors that increase job satisfaction in education (Song \& Mustafa, 2015).

In a national study with 1,194 K-12 Brazilian teachers from public and private schools, Author (2013) tested an integrative model comprised of environmental and personal predictors of job satisfaction. The study found that the strongest predictors of teachers' job satisfaction included the tendency to experience a positive emotional state (positive affect), the ability to create work-related goals and make progress toward them (goal progress), and the belief teachers hold about their own capacity to successfully plan and follow through on their professional activities (teachers' self-efficacy). This study also found that demographic characteristics—such as the type of school in which teachers work and the grade level they teach—were associated with teachers' job satisfaction. Private school and kindergarten teachers reported higher levels of job satisfaction (Author, 2013).

\subsection{Entrepreneurship and Job Satisfaction}

The connection between entrepreneurship and job satisfaction has been explored for the self-employed entrepreneur, expressing elements of job satisfaction that include creating a positive business image, financial benefits, close relationships with employees, autonomy, creativity, and social/community networks (Ayranci \& Ayranci, 2015; Prottas, 2008; Roche, 2015; Yetim \& Yetim, 2006). 
But studies exploring the association between job satisfaction and entrepreneurial behavior in education are rare. Kenney (2009) studied the job satisfaction perceptions of academic-entrepreneur faculty versus traditional faculty in the United States. Among 227 higher education respondents in three non-profit universities across all disciplines, $42.5 \%$ identified themselves as being academic entrepreneurs, but their levels of job satisfaction were no greater than those of their traditional colleagues.

Another study explored teachers' entrepreneurial activities and analyzed behaviors associated with these activities (Oplatka, 2014). Using semi-structured interviews with $30 \mathrm{~K}-12$ teachers and ten K-12 principals in the Israeli education system, the author identified several characteristics contributing to these behaviors: organizational commitment, indifference toward rewards, and job satisfaction. He concluded that job satisfaction was linked to behaviors associated with the teacher's entrepreneurial activities (Oplatka, 2014). Although these two studies hinted at potential connections between job satisfaction and entrepreneurship, each reported a different outcome. Further studies in this area are required to shed light on these contradictory findings.

\subsection{Contributions to the Literature}

This study addresses two research questions: (1) What is the relationship between entrepreneurship and job satisfaction among teachers? (2) Which demographic characteristics are associated with entrepreneurship and job satisfaction?

By addressing these questions, the contributions of this study to the literature are threefold. 
First, our research focuses on investigating the entrepreneurship phenomenon from a teacher's perspective within the educational context. This perspective is opposed to investigating entrepreneurship in other organizational contexts, such as large companies or technological enterprises, which have been widely investigated in studies on entrepreneurship. Therefore, the study simultaneously contributes to the fields of entrepreneurship and education by providing a particular and different angle of analysis, in which teachers are viewed as potential entrepreneurs within their environment and potential role models for igniting entrepreneurial behavior in their students.

Second, even though there have been studies focusing on both entrepreneurial behavior and job satisfaction separately, it is a first attempt towards examining the relationship between entrepreneurial behavior and teachers' job satisfaction. In this sense, both variables under analysis in this paper (entrepreneurial behavior and teacher's jobs satisfaction) have already been explored in the literature, however the relationship between them is a novel contribution. To the best of the authors' knowledge, this is the first such study.

Third, this study contributes to the enhancement of the competency-based perspective on entrepreneurship - as opposed to the trait-based perspective (i.e. entrepreneurs are naturally born with certain traits that supports their development) (Van Dam et al., 2010) - by embedding demographic characteristics and aspects into the discussion of entrepreneurial behavior among teachers. The theoretical framework on entrepreneurship supporting this research is based entirely on the competency-based perspective.

\section{Method}

\subsection{Procedure and participants}


To comprise a convenience sample of Brazilian teachers who were teaching in any grade level from kindergarten to high school, this study employed a snowball sampling strategy. The first round of invitations to teachers were sent across all regions of the country, covering many Brazilian states and different institutions. Brazilian teachers were asked to respond the online survey and to share the link to the questionnaire with other teachers who met the following criteria: (a) currently teaching, (b) teaching in private and/or public schools in Brazil, (c) teaching in any grade level from kindergarten to high school, and (d) older than 18 . Since Brazilian teachers typically participate in many different cross-institutional formal arrangements (e.g. unions, associations, clubs etc.) and informal groups (e.g. social media groups, mailing lists, study groups etc.), the survey's outreach was enhanced to cover a greater number of educational institutions across the country.

A total of 469 records were collected for this study. However, 84 were removed from the data due to the inclusion criteria and a very small number of items answered. The remaining sample consisted of 385 teachers (317 women, 68 men). They taught in public $(n=277,72 \%)$ or private schools $(n=88,23 \%)$ or both $(n=20,5 \%)$. The grade levels taught were kindergarten $(n$ $=111,29 \%)$, elementary $(n=17,45 \%)$, and high school $(n=99,26 \%)$.

\subsection{Measures}

\section{Demographics}

Participants were asked about their age, gender, highest degree achieved, the type of school they teach in, years of teaching experience, and grade levels taught.

\section{Entrepreneurial Behavior Scale}


Entrepreneurial behavior was measured by a 17-item scale developed by Van Dam et al. (2010). The items that comprise this scale are rated on a 5-point Likert scale ( $1=$ definitely not true; 5 = definitely true). Examples of items are "I took initiative, even when others did not" and "I usually was the last one to learn about upcoming changes". Cronbach's alpha was .75.

\section{Teachers' Job Satisfaction}

Developed by Skaalvik and Skaalvik (2015), this four-item scale assesses the level of enjoyment and reward drawn from work. Items are rated on a 5-point Likert scale ranging from 1 (strongly disagree) to 5 (strongly agree). The scale includes items such as "I enjoy working as a teacher" and "Working as a teacher is extremely rewarding". Cronbach's alpha was .86.

\subsection{Analyses}

To identify the demographic characteristics associated with entrepreneurial behavior and job satisfaction, and to assess the relationship between entrepreneurial behavior and job satisfaction, we performed analysis of frequency, analysis of variance (ANOVA), $t$-test and Pearson Product-Moment Correlation. In addition, Cronbach's alpha was calculated to assess the internal consistency reliability of the scales used in this study.

\section{Results}

4.1. Demographic characteristics associated with entrepreneurial behavior and job satisfaction A series of independent sample $t$-tests and analysis of variance (ANOVA) were performed to identify the demographic characteristics associated with entrepreneurial behavior and job satisfaction.

Independent Samples t-tests. 
The series of $t$-tests investigated mean differences for entrepreneurial behavior and job satisfaction between the two independent gender groups of females vs. males. Significant mean differences were found for entrepreneurial behavior, indicating that male teachers $(M=3.62, S D$ $=.40, \mathrm{~N}=68)$ had significantly higher mean scores than the females $(\mathrm{M}=3.44, \mathrm{SD}=.39, \mathrm{~N}=$ $317), \mathrm{t}(383)=-3.36, \mathrm{p}<.001$. Significant difference was not noted between female $(\mathrm{M}=3.77$, $\mathrm{SD}=.89)$, and male $(\mathrm{M}=3.91, \mathrm{SD}=.84)$ teachers for job satisfaction, $\mathrm{t}(383)=-1.22, \mathrm{p}=.224$. Analysis of Variance (ANOVA)

A series of one-way between-group analyses of variance tests (ANOVA) were performed, five sets (age, grade levels taught, highest degree achieved, the type of school in which they teach, and years of teaching experience) for each of the dependent variables of entrepreneurial behavior and job satisfaction.

Age

The first series of ANOVA analyses included the independent variable of age, which was divided into four groups (Group 1: 18-29; Group 2: 30-39; Group 3: 40-49; Group 4: 50-59) for this series of ANOVA analyses.

Table 1 presents the findings for the ANOVA tests. No significant difference was found.

Table 1

Results of ANOVA Findings for Age

\begin{tabular}{lllll}
\hline Variable/Group & $n$ & $M$ & $S D$ & $F$ \\
\hline & & & & 0.33 \\
Entrepreneurial Behavior & & & & \\
$18-29$ & 71 & 3.48 & 0.37 & \\
$30-39$ & 141 & 3.47 & 0.40 & \\
$40-49$ & 114 & 3.44 & 0.38 &
\end{tabular}


$\begin{array}{llll}50-59 & 59 & 3.51 & 0.44\end{array}$

Job Satisfaction

18-29

30-39

$40-49$

$50-59$

\begin{tabular}{llll} 
& & & 1.25 \\
71 & 3.80 & 0.78 & \\
141 & 3.69 & 0.87 & \\
114 & 3.86 & 0.92 & \\
59 & 3.91 & 0.92 & \\
\hline
\end{tabular}

Note. $M=$ Mean; $S D=$ Standard Deviation.

\section{Grade Level}

The second series of ANOVA analyses included the independent variable grade level, which was divided into three groups (Group 1: Kindergarten; Group 2: Fundamental; Group 3: High School).

The results presented in Table 2 show that at least one group differs on entrepreneurial behavior. The Post hoc comparisons using the Bonferroni Test indicate that high school teachers reported significantly higher entrepreneurial behavior than fundamental and kindergarten teachers.

Table 2

Results of ANOVA Findings for Grade Level

\begin{tabular}{lllll}
\hline Variable/Group & $n$ & $M$ & $S D$ & $F$ \\
\hline Entrepreneurial Behavior & & & & $7.02^{* * *}$ \\
$\quad$ Kindergarten & 111 & 3.46 & 0.35 & \\
$\quad$ Fundamental & 175 & 3.41 & 0.38 & \\
High School & 99 & 3.60 & 0.44 & \\
& & & & 1.22 \\
Job Satisfaction & & & & \\
$\quad$ Kindergarten & 111 & 3.90 & 0.82 & \\
$\quad$ Fundamental & 175 & 3.80 & 0.91 &
\end{tabular}


Note. ${ }^{* * *} p<.001 . M=$ Mean; $S D=$ Standard Deviation.

\section{Highest Degree Achieved}

This series of ANOVA analyses included the independent variable of highest degree achieved, which was divided into four groups (Group 1: High School; Group 2: College; Group 3: Specialization; Group 4: Masters).

The results shown in Table 3 indicate that at least one group differs on entrepreneurial behavior. The Post hoc comparisons using the Bonferroni Test indicate that those teachers with Specialization degrees have a significantly higher entrepreneurial behavior score than those with only high school. Also, those with Master's degrees scored significantly higher on entrepreneurial behavior than those with high school and college degrees.

\section{Table 3}

Results of ANOVA Findings for Highest Degree Achieved

\begin{tabular}{lllll}
\hline Variable/Group & $n$ & $M$ & $S D$ & $F$ \\
\hline & & & & $7.07 * * *$ \\
Entrepreneurial Behavior & & & & \\
$\quad$ High School & 20 & 3.25 & 0.36 & \\
College & 122 & 3.40 & 0.35 & \\
$\quad$ Specialization & 196 & 3.50 & 0.40 & \\
Masters & 47 & 3.65 & 0.42 & \\
& & & & \\
Job Satisfaction & & & & \\
$\quad$ High School & 20 & 3.74 & 0.87 & \\
College & 122 & 3.86 & 0.90 & \\
$\quad$ Specialization & 196 & 3.74 & 0.90 & \\
$\quad$ Masters & 47 & 3.89 & 0.75 & \\
\hline
\end{tabular}

Note. $* * * p<.001 . M=$ Mean; $S D=$ Standard Deviation. 
Type of School

The fourth series of ANOVA analyses included the independent variable type of school, which was divided into three groups (Group 1: Private; Group 2: Public; Group 3: Both).

The results for this series of ANOVA tests are presented in Table 4. No significant difference was found.

Table 4

Results of ANOVA Findings for Type of School

\begin{tabular}{lllll}
\hline Variable/Group & $n$ & $M$ & $S D$ & $F$ \\
\hline Entrepreneurial Behavior & & & & \multirow{2}{*}{1.30} \\
$\quad$ Private & 88 & 3.46 & 0.38 & \\
$\quad$ Public & 277 & 3.47 & 0.39 & \\
Both & 20 & 3.61 & 0.12 & \\
& & & & \multirow{2}{*}{05} \\
Job Satisfaction & & & & \\
$\quad$ Private & 88 & 3.91 & 0.80 & \\
$\quad$ Public & 277 & 3.76 & 0.55 & \\
$\quad$ Both & 20 & 3.81 & 0.21 & \\
\hline
\end{tabular}

Note. $M=$ Mean; $S D=$ Standard Deviation.

Years of Teaching Experience

The final series of ANOVA analyses included the independent variable of years of teaching experience, which was divided into five groups (Group 1: 1 to 5; Group 2: 6 to 10; Group 3: 11 to 15; Group 4: 16 to 20; Group 5: More than 20) for this series of ANOVA analyses. 
Table 5 presents the findings for the ANOVA tests. No significant difference was found.

Table 5

Results of ANOVA Findings for Years of Teaching Experience

\begin{tabular}{lllll}
\hline Variable/Group & $n$ & $M$ & $S D$ & $F$ \\
\hline & & & & 1.63 \\
Entrepreneurial Behavior & & & & \\
1 to 5 & 111 & 3.43 & 0.38 & \\
6 to 10 & 87 & 3.44 & 0.37 & \\
11 to 15 & 51 & 3.57 & 0.35 & \\
16 to 20 & 63 & 3.48 & 0.44 & \\
More than 20 & 73 & 3.52 & 0.43 & \\
& & & & \\
Job Satisfaction & & & & \\
1 to 5 & 111 & 3.83 & 0.84 & \\
6 to 10 & 87 & 3.73 & 0.87 & \\
11 to 15 & 51 & 3.63 & 0.88 & \\
16 to 20 & 63 & 3.81 & 0.97 & \\
More than 20 & 73 & 3.92 & 0.87 & \\
\hline
\end{tabular}

Note. $M=$ Mean; $S D=$ Standard Deviation.

\section{Further Exploration}

The series of t-tests and ANOVAs found that three of the demographic variables measured (gender, grade level, and highest degree achieved) are associated with entrepreneurial behavior. These results indicate the need for further exploration of the data to answer the following question: do the differences on entrepreneurial behavior discovered for each one of these variables hold when controlled for the other variables? In other words, does the effect of highest degree achieved (or gender or grade level), for example, still remain when we control for 
grade level (or gender or highest degree achieved) and gender (or grade level or highest degree achieved)?

To answer this question, a series of factorial ANOVAs was conducted. The results presented in Table 6 indicate that both gender and the highest degree achieved have an effect on entrepreneurial behavior, after controlling for the other two variables, but grade level is no longer significant at the 0.05 level.

Table 6

Results of factorial ANOVA for Gender, Grade Level and Highest Degree Achieved

\begin{tabular}{lllll}
\hline Source of Variation & $S S$ & $d f$ & $M S$ & $F$ \\
\hline Gender & .964 & 1 & .964 & $6.629^{*}$ \\
Grade Level & .727 & 2 & .363 & 2.498 \\
Highest Degree Achieved & 2.283 & 3 & .761 & $5.232^{* *}$ \\
\hline
\end{tabular}

Note. $* p<.05 ; * * p<.01$.

4.2. Relationship between entrepreneurial behavior and job satisfaction

To assess the relationship between entrepreneurial behavior and job satisfaction, a series of Pearson's product moment correlations were performed to compare bi-variate associations of the inferential analysis variables. The results of this test indicate a moderate positive correlation between entrepreneurial behavior and job satisfaction $(\mathrm{r}=.311, \mathrm{p}<.001)$. This relationship suggests that as entrepreneurial behavior increases, job satisfaction also increases, and viceversa. 


\section{Discussion}

This study aimed to explore the relationship between teachers' job satisfaction and entrepreneurial behavior, and to identify the demographic characteristics associated with both variables. To do so, the authors examined entrepreneurial behavior from a competency-based perspective as it relates to teachers' job satisfaction. This examination was supported by statistical analysis of data from 385 Brazilian teachers. The findings indicate a statistically moderate correlation between entrepreneurial behavior and teachers' job satisfaction. The results also show that gender and highest degree achieved account for more substantial effects in entrepreneurial behavior.

The results from the statistical analysis allow a first attempt towards linking entrepreneurial behavior and job satisfaction. Since this research is exploratory in nature and causality between the variables is not defined, we cannot determine which variable actually causes the other. In other words, does entrepreneurial behavior lead to teachers' job satisfaction, or vice-versa? However, a number of insights can be drawn from the correlation found.

Unsatisfied teachers display high levels of stress and concerns in the classroom, as constant time pressures — coupled with behavioral and disciplinary issues—directly affect them (Matsuoka, 2015; Skaalvik \& Skaalvik, 2015; Tran, 2015). This could indicate that unsatisfied teachers have neither intrinsic motivation nor enough focus to explore innovative ideas with their students. On the other hand, satisfied teachers are driving forces of student engagement, overall increases in educational outcomes, and teacher retention, as pointed out by Hoekstra (2014), Kitchel et al. (2012), Song and Mustafa (2015), and others. Within this particular context, satisfied teachers might become even more stimulated by the positive outcomes of their efforts- 
reflected, among other things, in their students' achievements—and be on the lookout for new opportunities, and taking initiative and calculated risks when such opportunities arise, laying out the foundations for entrepreneurial behavior (Van Dam et al., 2010) and reinforcing their satisfaction.

Satisfied teachers might have more open communication with their students, showing a higher inclination towards receiving their feedback. Job satisfaction can work as a motivator for continuously improving professional practices and bringing more innovative elements to the classroom. Since teachers' job satisfaction is closely linked to healthier working conditions, performance incentives, professional esteem and recognition, job security, supportive administration, and higher levels of autonomy (Foor \& Cano, 2011; Matsuoka, 2015; Skaalvik \& Skaalvik, 2015; Tran, 2015), more-satisfied teachers are better equipped with the focus and the motivation to explore their own creative capabilities for the materialization of innovative projects. It is important to note that this could possibly be a self-reinforcing process: satisfied teachers derive more innovation-based and entrepreneurial endeavors, which in turn feed back into their own job satisfaction.

Conversely, lower levels of entrepreneurial behavior could lead to diminished job satisfaction among teachers. If teachers have been working in a very stable or inflexible environment, teaching the same materials and classes over the past several years, they display lower inclination towards adopting unpredictable and uncertain practices - typical facets of entrepreneurship - in their classrooms (Van Dam et al., 2010). This lack of opportunity for innovation and creativity could result in lower job satisfaction. Students increasingly expect teachers to be innovative and uncommon in their approaches and materials. By not meeting those 
expectations, teachers may negatively affect their own beliefs about their ability to produce desired outcomes. These beliefs are known as self-efficacy, which has been identified as a predictor of teachers' job satisfaction (Author, 2013). Furthermore, entrepreneurial behavior facilitates the adoption of recently-launched technologies that can enrich students' learning experience. Therefore, lower entrepreneurial behavior could cause a mismatch between students' expectations and teachers' attitude towards the implementation of technology-based projects, with a negative impact on the way teachers feel about their jobs.

Higher levels of entrepreneurial behavior among teachers might drive superior job satisfaction. Teachers' high entrepreneurial behavior reflects their ability to raise funds, gather resources, and plan and coordinate new projects with the objective of creating a more enjoyable, technology-enabled, and tools-enriched learning environment. This behavior can be capitalized in tangible outcomes, such as better incentives, recognition and praise from students, school administrators, and, in some cases, society at large. This leads teachers to experience a positive emotional state known as positive affect. Positive affect has been identified as a strong predictor of job satisfaction (Author, 2013). These outcomes may boost teachers' job satisfaction and reinforce entrepreneurial behavior.

In examining particular demographic elements, gender has a significant influence in entrepreneurial behavior, with men displaying higher levels of entrepreneurial behavior. This result aligns with the literature, showing a higher prevalence of entrepreneurship among men-a result that is constant when tested in different cultures and nationalities. However, most of the explanation comes from (i) ingrained gender stereotypes against women entrepreneurs (Marlow \& Patton, 2005); (ii) entrepreneurship being constantly associated with masculine traits (Ahl, 
2006; Lewis, 2006), and (iii) women facing more challenges and difficulties compared to men, which results from less favorable perceptions of themselves and the entrepreneurial environment due to higher self-imposed obstacles to growth (Langowitz \& Minniti, 2007; Zhang et al., 2009). A potential explanation is that female teachers, despite comprising the immense majority of Brazilian teachers, are subjected to more challenges and difficulties in exploring potentially entrepreneurial projects. They may also be systematically exposed to deep-rooted societal gender inequalities. Therefore, we could argue that female teachers do not perceive the potential benefits of following an entrepreneurial-oriented path. Women who do perceive those potential benefits may often find their attempts to embrace this path undermined by various circumstances and agents.

Complementarily to gender, the highest degree achieved also exerts a strong influence on entrepreneurial behavior. Teachers holding specialization and masters' degrees show higher levels of entrepreneurial behavior compared with teachers holding only bachelors' or high school degrees. This finding confirms Van Dam et al.'s (2010) study, in which educational level was significantly related to entrepreneurial behavior, suggesting that teachers with higher levels of education show more entrepreneurial behavior. In that same study, a regression analysis showed that education was not a predictor of entrepreneurial behavior. However, the authors found a significant association between education level and entrepreneurial knowledge, with entrepreneurial knowledge a strong predictor of entrepreneurial behavior (Van Dam et al., 2010). In connection to the findings related to the degree achieved and regarding teacher preparation in general, programs have focused on providing candidates with requisite knowledge and imbuing a certain status as educational authorities (Aurini, 2004; Fairbanks et al., 2010). 
Recent years have emphasized teaching entrepreneurial skills to K-12 students to nurture their ability to creatively solve problems, gain access to scarce resources, and make learning more interactive and authentic (Ali et al., 2009; Foote, 2012; Webber \& Scott, 2008).

To propagate the concept of educational entrepreneurship, teachers need training in these practices. Teachers are currently trained to be technically competent, but not many of them respond effectively to students' needs or critical situations (Fairbanks et al., 2010). Proponents of entrepreneurial education suggest training for prospective teachers that includes such things as creative problem solving, capitalizing on opportunities, questioning the status quo, selfpromotion, and mastering the art of networking (Ali et al., 2009; Borasi \& Finnigan, 2010; Van Dam et al., 2010; Young, 2007). Universities are starting to recognize the potential benefits of this training to nascent teachers. Consider the example at the University of São Paulo in Brazil. The school has initiated a policy that all disciplines (including education) go beyond simply imparting knowledge to include such entrepreneurial training as developing innovative ideas, establishing community partnerships, and creating an entrepreneurial culture at the institution (Ortega \& Bagnato, 2015).

Still others suggest that entrepreneurial initiatives should go beyond training and practices to include development of internal factors and personal traits such as happiness, attitude, self-discipline, motivation, identity, and dismissing biases and preconceptions (Adeyemo, 2009; Dennis \& Parker, 2010; Lindgren \& Packendorff, 2008; O’Brien, 2013). Therefore, the association between highest degree achieved and entrepreneurial behavior in this study could be due to the widespread dissemination of short courses, lectures, talks, and online material on entrepreneurship and education across graduate programs in Brazilian institutions of 
higher education. Teachers who have attended graduate programs may be more intensively exposed to entrepreneurship stories, examples, role models, and theory. Moreover, professors could have also served as dissemination channels to teachers willing to engage with the entrepreneurship- and innovation-related subjects. Finally, the rapid emergence of products, services, and general discussions and interests around the topic of entrepreneurship in education could have also acted as driving forces and stimulus for teachers to bring innovative ideas to their own classrooms.

Surprisingly, other demographic characteristics, such as an individual's age, did not appear associated with entrepreneurial behavior. Using the data from the Global Entrepreneurship Monitor, Liang, Wang, and Lazear (2014) found that a country's lower median age is associated with higher levels of entrepreneurship, and societies with higher median ages display lower entrepreneurship activity. That would mean that older teachers could display lower entrepreneurial behavior due to their potential career stability, coupled with a more risk-averse profile. Younger teachers would show increased entrepreneurial behavior, driven by a stronger tendency to embrace risk and experiment with new elements in the classroom. On the other hand, years of teaching experience could be correlated with entrepreneurial behavior, since more experienced professionals would be in a better position to think and operationalize innovative efforts in the classroom due to their potentially larger and deeper understanding of education and the educational system as a whole. They could also have been exposed to more entrepreneurial experiences and venture attempts throughout their professional lives (e.g., Miralles, Giones, \& Riverola, 2015). 
Furthermore, Brazilian private schools are, to a large extent, better equipped with investments and resources, and attract teachers with more experience and higher degrees (Author, 2013). In theory, this could create a system more likely to foment entrepreneurial behaviors among teachers than public schools. However, our findings do not support this claim.

A word should be said about the lack of demographic characteristics associated with teachers' job satisfaction. While a previous study with Brazilian teachers found that those in private schools and teaching kindergarten were more satisfied (Author, 2013), the current study found no such association. It is reasonable to speculate that some differences in sampling between the two studies might have contributed to different results. The previous study had a much larger sample size $(1,194)$ compared to 385 in this study. The samples were different not only in numbers but also in other factors such as gender. About $29 \%$ of the participants in the 2013 sample were male, compared to only $17.7 \%$ of the current one. Further research is needed to clarify this issue.

The findings of this exploratory study open a strain of research on the connection between job satisfaction and entrepreneurial behavior in the educational field. They also add to the studies on entrepreneurship in education and to the competency-based perspective on the studies of entrepreneurship. Beyond these theoretical contributions, this study also has practical implications for educators and leaders in the educational field, who are mainly policy-oriented.

A practical implication regarding the gender finding could clearly go in the direction of defining robust policies targeted at women to stimulate their interest in the subject and significantly increase their likelihood of succeeding in entrepreneurial activities in the classroom as a way of improving their own satisfaction and performance. Such diversity-oriented policies 
should also clearly work towards reducing the cultural and social barriers imposed by strong stereotypes and ingrained mental models of entrepreneurship as a masculine characteristic. They could approach these goals by promoting wider discussions, showcasing feminine entrepreneurial achievements and joining forces with ongoing initiatives for women in entrepreneurship, both at the local and national levels.

Another practical implication has to do with the highest degree achieved. This study can serve as a motivator to foster nationwide programs for the systematic integration of entrepreneurship training in the earlier stages of formal education-especially in high school and college — when flexibility and the possibility of exploring engaging and transformational experiences are higher. This integration could take various forms, such as periodic engaging events, short courses, boot camps, curricular and/or elective courses, and specialization tracks.

While this study provides theoretical contributions to the study of entrepreneurial behavior from a competency-based perspective and practical implications to the educational field, it has limitations. Given its exploratory nature, it was limited to descriptive statistics, correlations and means differences focusing on the demographical characteristics of participants, and the relationship between entrepreneurial behavior and teachers' job satisfaction. While these tests were enough to achieve the goal of the study, the design precluded causal inferences. The snowball sampling technique used for data collection was based on the participants' social networks and demanded the use of the Internet, which may have biased sampling toward those more social and living in larger cities with easier Internet access. Despite this potential bias, it is worth pointing out that — based on the most recently educational census (Fraga, 2016) — the sample reflects the overall characteristics of Brazilian teachers in terms of gender and type of 
school in which they teach. In this study, $82.3 \%$ of participants were female, while $80.1 \%$ of all Brazilian teachers are female. Also, $71.9 \%$ of participants in this study worked in public schools while $76.8 \%$ of Brazilian teachers do so.

Future research efforts could point to a number of potential directions by: (i) qualitatively exploring and characterizing the mechanisms behind the correlation between job satisfaction and entrepreneurial behavior, with a view to describing the main driving factors of this correlation. Specifically exploring entrepreneurial behavior, qualitative studies could assess how teachers see themselves as entrepreneurs and identify some of the activities or projects that highlight their entrepreneurial behavior; (ii) investigating the effects of other competencies significantly correlated with entrepreneurial behavior, such as career adaptability, self-efficacy, or creative thinking; (iii) specifically examining how the teaching and entrepreneurial environment (organizational climate) influences the correlation between job satisfaction and entrepreneurial behavior; (iv) performing cross-cultural and cross-national quantitative studies to check the consistency of the findings we presented in this study. 


\section{References}

Adeyemo, S. A. (2009). Understanding and acquisition of entrepreneurial skills: A pedagogical re-orientation for classroom teacher in science education. Journal of Turkish Science Education, 6(3), 57-65.

Ahl, H. (2006). Why research on women entrepreneurs needs new directions. Entrepreneurship: Theory and Practice, 30(5), 595-621.

Ali, A., Topping, K. J., \& Tariq, R. H. (2009). Entrepreneurial inclinations of prospective teachers. New Horizons in Education, 56(2), 1-16.

Author. (2013). [Details removed for peer review]

Aurini, J. (2004). Educational entrepreneurialism in the private tutoring industry: Balancing profitability with the humanistic face of schooling. The Canadian Review of Sociology and Anthropology, 41(4), 475-491.

Aurini, J., \& Quirke, L. (2011). Does market competition encourage strategic action in the private education sector? Canadian Journal of Sociology, 36(2), 173-197.

Ayranci, A. E. \& Ayranci, E. (2015). A research on job satisfaction factors of private entrepreneurs: The case of Beylikduzu Organized Industrial Zone. Procedia Social and Behavioral Sciences, 195, 268-277.

Borasi, R., \& Finnigan, K. (2010). Entrepreneurial attitudes and behaviors that can help prepare successful change-agents in education. The New Educator, 6, 1-29.

Bradley, D. E., \& Roberts, J. A. (2004). Self-employment and job satisfaction: Investigating the role of self-efficacy, depression, and seniority. Journal of Small Business Management, 42(1), 37-58. 
Burke, R. J., \& McKeen, C. A. (1990). Mentoring in organizations: Implications for women. Journal of Business Ethics, 9(4), 317-332.

Burke, R. J., McKeen, C. A., \& McKenna, C. (1994). Benefits of mentoring in organizations: Them mentor's perspective. Journal of Managerial Psychology, 9(3), 23-32.

Carland, J. W., Hoy, F., \& Carland, J. C. (1988). Who is an entrepreneur? Is a question worth asking. American Journal of Small Business, 12(4), 33-39.

Carree, M. A., \& Verheul, I. (2012). What makes entrepreneurs happy? Determinants of satisfaction among founders. Journal of Happiness Studies, 13(2), 371-387.

Chand, V. S. (2014). Socio-educational entrepreneurship within the public sector: Leveraging teacher-driven innovations for improvement. In A. W. Wiseman (Ed.), International Educational Innovation and Public Sector Entrepreneurship: International Perspectives on Education and Society. Volume 23 (pp. 59-82). Bingley, UK: Emerald Group Publishing.

Chell, E. (1985). The entrepreneurial personality: A few ghosts laid to rest? International Small Business Journal, 3(3), 43-54.

Chell, E. (2000). Towards researching the "opportunistic entrepreneur": A social constructionist approach and research agenda. European Journal of Work and Organizational Psychology, 9(1), 63-80.

Cools, E., \& den Broeck, H. V. (2007). The hunt for the heffalump continues: Can trait and cognitive characteristics predict entrepreneurial orientation? Journal of Small Business Strategy, 18(2), 23-42. 
Davis, V. (2009). Influencing positive change: The vital behaviors to turn schools toward success. Teacher Librarian, 37(2), 8-12.

Dennis, D. V, \& Parker, A. (2010). Treating instructional malpractice: Reflexive protocols for entrepreneurial teachers. Childhood Education, 86(4), 249-254.

Fairbanks, C. M., Duffy, G. G., Faircloth, B. S., He, Y., Levin, B., Rohr, J., \& Stein, C. (2010). Beyond knowledge: Exploring why some teachers are more thoughtfully adaptive than others. Journal of Teacher Education, 61(1-2), 161-171.

Foor, R. M., \& Cano, J. (2011). Predictors of job satisfaction among selected agriculture faculty. Journal of Agricultural Education, 52(1), 30-39.

Foote, C. (2012). Edu-preneurship: Being more than "just a teacher". Retrieved from http://www.techlearning.com/news/0002/edupreneurship/64921.

Fraga, E. (2016, May 15). Professor tem formacao melhor na rede publica do que na particular. Folha de S. Paulo. Retrieved from http://www1.folha.uol.com.br

Fritsch, M., \& Wyrwich, M. (2016). The effect of entrepreneurship on economic developmentAn empirical analysis using regional entrepreneurship culture. Journal of Economic Geography. doi:10.1093/jeg/lbv049

Gunzenhauser, M. G. (2013). Ethics for the new political economy: What can it mean to be professionally responsible? Philosophical Studies in Education, 44, 10-28.

Hayton, J. C., \& Kelley, D. J. (2006). A competency-based framework for promoting corporate entrepreneurship. Human Resource Management, 45(3), 407-427.

Hoekstra, B. (2014). Relating training to job satisfaction: A survey of online faculty members. Journal of Adult Education, 43(1), 1-10. 
Kenney, M. G. (2009). The effect of academic entrepreneurship on overall faculty job satisfaction: A comparison of academic entrepreneurs and traditional professors. Proceedings of the United States Association for Small Business and Entrepreneurship Conference, 1224-1255. Retrieved from http://search.proquest.com.proxy.davenport.edu/docview/748841362?pqorigsite=summon $\&$ accountid $=40195 \#$.

Kitchel, T., Smith, A. R., Henry, A. L., Robinson, J. S., Lawver, R. G., Park, T. D., \& Schell, A. (2012). Teacher job satisfaction and burnout viewed through social comparisons. Journal of Agricultural Education, 53(1), 21-44.

Lange, T. (2012). Job satisfaction and self-employment: Autonomy or personality? Small Business Economics, 38(2), 165-177.

Langowitz, N., \& Minniti, M. (2007). The entrepreneurial propensity of women. Entrepreneurship: Theory and Practice, 31(3), 341-364.

Lewis, P. (2006). The quest for invisibility: Female entrepreneurs and the masculine norm of entrepreneurship. Gender, Work and Organization, 13(5), 453-469.

Liang, J., Wang, H., \& Lazear, E. P. (2014). Demographics and Entrepreneurship (No. 20506). http://dx.doi.org/10.3386/w20506

Lindgren, M., \& Packendorff, J. (2008). Woman, teacher, entrepreneur: On identity construction in female entrepreneurs of Swedish independent schools. In I. Aaltio, P. Kyrö \& E. Sundin (Eds.), Women entrepreneurship and social capital: A dialogue and construction (pp. 193225). Copenhagen: Copenhagen Business School Press. 
Lunenberg, M., Korthagen, F., \& Swennen, A. (2007). The teacher educator as a role model. Teaching and Teacher Education, 23(5), 586-601.

Maranto, R. (2015). Did the teachers destroy the school? Public entrepreneurship as creation and adaptation. Journal of School Leadership, 25(1), 69-101.

Marlow, S., \& Patton, D. (2005). All credit to men? Entrepreneurship, finance, and gender. Entrepreneurship: Theory and Practice, 29(6), 717-735.

Matsuoka, R. (2015). School socioeconomic context and teacher job satisfaction in Japanese compulsory education. Educational Studies in Japan: International Yearbook, 9, 41-54.

Miralles, F., Giones, F., \& Riverola, C. (2015). Evaluating the impact of prior experience in entrepreneurial intention. International Entrepreneurship and Management Journal, 12(3), 791-813.

O’Brien, C. (2013). Happiness and sustainability together at last! Sustainable happiness. Canadian Journal of Education, 36(4), 228-256.

Onstenk, J. (2003). Entrepreneurship and vocational education. European Educational Research Journal, 2(1), 74-89.

Omer Attali, M., \& Yemini, M. (2016). Initiating consensus: Stakeholders define entrepreneurship in education. Educational Review. doi:10.1080/00131911.2016.1153457

Oplatka, I. (2014). Understanding teacher entrepreneurship in the globalized society. Journal of Enterprising Communities: People and Places in the Global Economy, 8(1), 20-33.

Oppedisano, J., \& Laird, K. R. (2006). Entrepreneurship education for women and girls: An interactive model of transformational learning. New England Journal of Entrepreneurship, 9(2), 35-49. 
Ortega, L. M., \& Bagnato, V. S. (2015). The practice of innovation at Brazilian public university: The case of the University of Sao Paulo. Brazilian Journal of Science and Technology, 2(6), 1-15.

Petersen, J. L. (2014). For education entrepreneurs, innovation yields high returns. Education Next, 14(2), 8-16.

Prottas, D. (2008). Do the self-employed value autonomy more than employees? Career Development International, 13(1), 33-45.

Rietveld, C. A., Hessels, J., \& Van Der Zwan, P. (2015). The stature of the self-employed and its relation with earnings and satisfaction. Economics and Human Biology, 17, 59-74.

Roche, K. (2015). Job satisfaction and the educated entrepreneur. Journal of Small Business \& Entrepreneurship, 27(4), 353-368.

Sankelo, M., \& Åkerblad, L. (2009). Nurse entrepreneurs’ well-being at work and associated factors. Journal of Clinical Nursing, 18(22), 3190-3199.

Sharra, S. (2005). From entrepreneurship to activism: Teacher autobiography, peace and social justice in education. Current Issues in Comparative Education, 8(1), 7-17.

Skaalvik, E. M., \& Skaalvik, S. (2015). Job satisfaction, stress and coping strategies in the teaching profession: What do teachers say? International Education Studies, 8(3), 181-192.

Song, S., \& Mustafa, M. (2015). Factors impacting on teachers' job satisfaction related to science teaching: A mixed methods study. Science Education International, 26(3), 358-375.

Tolentino, A. (1998). Training and development of entrepreneurs-managers of small enterprises: Pointers and lessons learned. Geneva: International Labour Organization. 
Tran, V. D. (2015). Effects of gender on teacher's perceptions of school environment, teaching efficacy, stress and job satisfaction. International Journal of Higher Education, 4(4), 147157.

Tülüce, N. S., \& Yurtkur, A. K. (2015). Term of strategic entrepreneurship and Schumpeter's creative destruction theory. Procedia-Social and Behavioral Sciences, 207, 720-728.

Van Dam, K., Schipper, M., \& Runhaar, P. (2010). Developing a competency-based framework for teachers' entrepreneurial behaviour. Teaching and Teacher Education, 26(4), 965-971.

Webber, C. F., \& Scott, S. (2008). Entrepreneurship and educational leadership development: Canadian and Australian perspectives. International Electronic Journal for Leadership in Learning, 12(14), 1-15.

Yetim, N., \& Yetim, U. (2006). The cultural orientations of entrepreneurs and employees' job satisfaction: The Turkish small and medium sized enterprises (SMEs) case. Social Indicators Research, 77(2), 257-286.

Young, M. (2007). More than prize lists: Head teachers, student prize winners, school ceremonies and educational promotion in colonial South Australia. International Education Journal, $8(2), 49-59$.

Zhang, Z., Zyphur, M. J., Narayanan, J., Arvey, R. D., Chaturvedi, S., Avolio, B. J., ... Larsson, G. (2009). The genetic basis of entrepreneurship: Effects of gender and personality. Organizational Behavior and Human Decision Processes, 110(2), 93-107. 